\title{
Immunological Identification of a Nicotinic Acetylcholine Receptor on Bovine Chromaffin Cells
}

\author{
Linda S. Higgins and Darwin K. Berg \\ Department of Biology, University of California, San Diego, La Jolla, California 92093
}

Two probes previously shown to distinguish the nicotinic ACh receptor of chick ciliary ganglion neurons also recognize a component on the surface of bovine chromaffin cells in culture that displays the properties expected for the chromaffin nicotinic $\mathrm{ACh}$ receptor. The first probe is a monocional antibody, $\mathrm{mAb} 35$, raised against $\mathrm{ACh}$ receptor from Electrophorus electric organ, and the second is an $\alpha$-neurotoxin, Bgt 3.1, purified from $B$. multicinctus venom. mAb 35 binds specifically to a single class of high-affinity sites on the chromaffin cells in culture. Scatchard analysis indicates a $K_{D}$ of $2.1 \pm 0.2 \mathrm{nM}$ for the binding and $\mathrm{a} B_{\max }$ of $1.6 \pm 0.1 \times$ $10^{4} \mathrm{mAb} 35$ sites per cell. The number of sites on the cells can be reduced through modulation by exposure of the cells to Bgt 3.1. The modulation can be blocked by the cholinergic ligands $d$-tubocurarine and carbamylcholine. Long-term exposure to the agonist carbamylcholine alone also reduces the number of $\mathrm{mAb} 35$ binding sites. Bgt 3.1 inhibits nicotineinduced catecholamine release from the cells to the same extent and with the same concentration dependence that it modulates the number of mAb 35 sites on the cells. In addition, mAb 35 treatment of the cells causes a specific and almost complete blockade of nicotine-induced catecholamine release, apparently through a modulation of the receptor. These results indicate that the bovine chromaffin component recognized by $\mathrm{mAb} 35$ and Bgt 3.1 is likely to be the nicotinic $A C h$ receptor on the cells and that it has many similarities to $A C h$ receptors on chick autonomic neurons.

Nicotinic acetylcholine receptors (AChRs) mediate the major form of synaptic input to chromaffin cells of the bovine adrenal medulla (for review, see Livett, 1984). Biochemical characterization of chromaffin AChRs has been hampered by a lack of suitable probes identifying the receptor protein. $\alpha$-Bungarotoxin ( $\alpha$-Bgt), an $\alpha$-neurotoxin that binds tightly and specifically to AChRs from skeletal muscle and electric organ, recognizes a class of binding sites on bovine chromaffin cells, but the relationship of the sites to AChRs on the cells is unknown. $\alpha$-Bgt at concentrations adequate to saturate the sites does not block AChR function on chromaffin cells (Trifaro and Lee, 1980; Kil-

\footnotetext{
Received Aug. 26, 1986; revised Nov. 26, 1986; accepted Dec. 4, 1986.

We thank Dr. Jon Lindstrom for giving us the hybridoma cell line that produces $\mathrm{mAb} 35$. Grant support was provided by the National Institutes of Health (NS 12601), the Muscular Dystrophy Association, and the American Heart Association with funds contributed in part by the California Heart Association. L.S.H. is a National Science Foundation Predoctoral Fellow.

Correspondence should be addressed to Darwin K. Berg, Department of Biology, University of California, San Diego, La Jolla, CA 92093.

Copyright (C) 1987 Society for Neuroscience $0270-6474 / 87 / 061792-07 \$ 02.00 / 0$
}

patrick et al., 1981), in contrast to its effective blockade of AChR function in muscle and electric organ (Fambrough, 1979). A second neurotoxin, P-4 bungarotoxin, does block ACh-induced secretion of catecholamines from bovine chromaffin cells (Saiani et al., 1984). Specific binding of radiolabeled P4 to chromaffin cells has been reported (Costa et al., 1983), but a characterization of the binding sites has yet to be described.

Chromaffin AChRs are likely to be similar to ganglionic AChRs of the autonomic nervous system since chromaffin cells share many properties with sympathetic neurons: both derive from the neural crest, generate action potentials, synthesize and release catecholamines, and receive synaptic input from preganglionic neurons in the spinal cord. Two probes have been shown to identify $\mathrm{AChRs}$ on chick autonomic neurons. One is a monoclonal antibody, mAb 35, to the "main immunogenic region" (MIR) of muscle and electric organ AChR $\alpha$-subunits. mAb 35 cross-reacts with a component on chick ciliary ganglion neurons that has the synaptic location, biochemical properties, tissue distribution, and cholinergic modulation expected for the AChR of the neurons (Jacob et al., 1984; Smith et al., 1985, 1986). Though mAb 35 does not itself block AChR function, it has been used to immunopurify a component from chicken brain (Whiting and Lindstrom, 1986) that induces antisera capable of specifically blocking the ACh sensitivity of ciliary ganglion neurons in cell culture (Stollberg et al., 1986). These observations are consistent with both the brain and ganglionic components recognized by $\mathrm{mAb} 35$ being functional neuronal $\mathrm{AChRs}$.

The second probe that recognizes AChRs on chick autonomic neurons is a protein $\alpha$-neurotoxin, $\mathrm{Bgt} 3.1$, that reversibly blocks receptor function (Ravdin and Berg, 1979; Ravdin et al., 1981). Bgt 3.1 appears to be indistinguishable from $\kappa$-bungarotoxin and toxin F (Loring et al., 1986), toxins purified independently from the same source and shown to block AChR function in the ciliary ganglion (Chiappinelli, 1983; Loring et al., 1984). Bgt 3.1, with a size of about $7 \mathrm{kDa}$ (Ravdin and Berg, 1979), is clearly distinct from P-4 bungarotoxin, with a size of about $15 \mathrm{kDa}$ (Saiani et al., 1984). Amino acid composition and amino acid sequence data also indicate they are different (Saiani et al., 1984; Grant and Chiappinelli, 1985; Loring et al., 1986). Binding studies with radiolabeled Bgt 3.1 demonstrate that the toxin distinguishes a class of sites on ciliary ganglion neurons in cell culture that has the affinity, kinetics, pharmacology, and cell-type specificity expected for the neuronal AChR (Halvorsen and Berg, 1986a). Cross-linking studies with a photoaffinity derivative of Bgt 3.1 confirm that $\mathrm{mAb} 35$ and Bgt 3.1 recognize the same component on the neurons (Halvorsen and Berg, 1986b, 1987). The AChR identified in this manner is physically distinct from the membrane component of unknown function on the neurons 
that binds $\alpha$-Bgt (Jacob and Berg, 1983; Smith et al., 1983, 1985; Jacob et al., 1984).

We show here that mAb 35 and Bgt 3.1 identify a component on bovine chromaffin cells in culture that displays many similarities to the $\mathrm{AChR}$ on chick ciliary ganglion neurons. Moreover, mAb 35 specifically modulates chromaffin AChR function, supporting the identity of the component as the receptor. The amount of AChR present in the bovine adrenal medulla is sufficient to permit purification of the receptor. Some of these results have been described in a preliminary account (Higgins and Berg, 1986).

\section{Materials and Methods}

Cell cultures. Bovine adrenal chromaffin cell cultures were prepared as previously described (Kilpatrick et al., 1980; Livett, 1984) with minor modifications. Bovine adrenal glands were obtained from a local slaughterhouse 20-30 min after the animals died and were transported in icecold $5.0 \mathrm{~mm}$ HEPES, pH 7.4 , containing $3.6 \mathrm{~mm} \mathrm{NaHCO}, 154 \mathrm{~mm}$ $\mathrm{NaCl}, 5.6 \mathrm{~mm} \mathrm{KCl}, 5.6 \mathrm{~mm}$ glucose, 50 units $/ \mathrm{ml}$ penicillin $\mathrm{G}$, and 50 $\mu \mathrm{g} / \mathrm{ml}$ streptomycin ( $\mathrm{Ca}^{2+}$-free Locke's solution). After cleaning the glands of external fat, they were rinsed and internally perfused with $\mathrm{Ca}^{2+}$-free Locke's solution. The glands were then inflated with $\mathrm{Ca}^{2+}$-free Locke's solution containing $0.2 \%(\mathrm{wt} / \mathrm{vol})$ collagenase and $0.015 \%(\mathrm{wt} / \mathrm{vol}) \mathrm{DNase}$, and incubated for $15 \mathrm{~min}$ at $37^{\circ} \mathrm{C}$. After repeating the incubation a second time with fresh solution, the cortices were removed, and the medullae were minced and incubated for $30 \mathrm{~min}$ at $37^{\circ} \mathrm{C}$ with stirring in a solution of the same composition. The resulting cell suspension was filtered through gauze, diluted with $\mathrm{Ca}^{2+}$-free Locke's solution containing $0.1 \%(\mathrm{wt} / \mathrm{vol}) \mathrm{BSA}$, and centrifuged at $100 \times g$ for $12 \mathrm{~min}$. The cell pellet was resuspended by trituration in $\mathrm{Ca}^{2+}$-free Locke's solution containing BSA.

Chromaffin cells were purified by centrifugation at $20,000 \times g$ for 20 min at $23^{\circ} \mathrm{C}$ in $\mathrm{Ca}^{2+}$-free Locke's solution containing $0.1 \% \mathrm{BSA}$ and $43 \%$ Percoll. The chromaffin cells were collected as a band near the middle of the tube and were diluted to a concentration of $10^{6}$ cells $/ \mathrm{ml}$ in Dulbecco's Modified Eagle's Medium (DMEM) containing 10\% (vol/ vol) heat-inactivated fetal bovine serum, 50 units $/ \mathrm{ml}$ penicillin $G, 50$ $\mu \mathrm{g} / \mathrm{ml}$ streptomycin, and $10^{-5} \mathrm{M}$ 5-fluorodeoxyuridine (culture medium). Cell viability, determined by Trypan blue exclusion, was estimated to be $>95 \%$. Typically, 6 glands were used for a cell preparation and yielded 2-8 $\times 10^{7}$ cells/gland. Cultures were prepared with $5 \times 10^{5}$ cells/well, unless otherwise indicated, on either Costar or Falcon $16 \mathrm{~mm}$ well culture plates. The cultures were maintained at $35^{\circ} \mathrm{C}$ in $5 \% \mathrm{CO}_{2} /$ $95 \%$ air, and received fresh medium every 2 days. Cytosine arabinoside was included in the medium at a final concentration of $10^{-5} \mathrm{M}$ after the first day.

Monoclonal antibodies. mAb 35 was raised against purified AChR from Electrophorus electric organ and recognizes the $\alpha$-subunit MIR (Tzartos et al., 1981). The mAb was purified from hybridoma culture media and radioiodinated to specific activities of $2-3 \times 10^{18} \mathrm{cpm} / \mathrm{mol}$ as previously described (Smith et al., 1985). mAbs 6 and 203 also recognize the MIR and were raised against AChR from Torpedo electric organ (Tzartos and Lindstrom, 1980) and human skeletal muscle (Tzartos et al., 1983), respectively. mAb 111 was raised against AChR from Torpedo electric organ and recognizes a determinant on the $\beta$-subunit of the receptor; it is an IgG $1 \mathrm{mAb}$, as is $\mathrm{mAb} 35$, and it does not crossreact with the MIR of the $\alpha$-subunit (Gullick and Lindstrom, 1983). mAbs 6,111 , and 203 were partially purified by ammonium sulfate precipitation from hybridoma culture media and were generously provided, along with the hybridoma cell line secreting $\mathrm{mAb} 35$, by Jon Lindstrom of the Salk Institute.

$m A b 35$ binding. mAb 35 binding to intact cells was determined by incubating cultures for $60 \mathrm{~min}$ at $37^{\circ} \mathrm{C}$ with $0.2 \mathrm{ml}$ medium containing $5 \mathrm{nM}{ }^{15} \mathrm{I}-\mathrm{mAb} 35$ (standard conditions) unless otherwise indicated. The cultures were then rinsed 4 times with $1 \mathrm{ml}$ aliquots of $5 \mathrm{~mm}$ HEPES, $\mathrm{pH} 7.4$, containing $137 \mathrm{~mm} \mathrm{NaCl}, 5.4 \mathrm{~mm} \mathrm{KCl}, 0.8 \mathrm{~mm} \mathrm{MgSO}_{4}, 0.9$ mM Na $\mathrm{PO}_{4}, 0.4 \mathrm{mM} \mathrm{KH} \mathrm{PO}_{4}, 1.8 \mathrm{mM} \mathrm{CaCl}_{2}, 5.6 \mathrm{~mm}$ glucose, and 2 $\mathrm{mg} / \mathrm{ml} \mathrm{BSA} \mathrm{(rinse} \mathrm{solution),} \mathrm{scraped} \mathrm{in} 0.5 \mathrm{ml}$ of $0.6 \mathrm{~N} \mathrm{NaOH}$, and analyzed for ${ }^{125}$ I with a Tracor analytic model 1191 gamma counter Nonspecific binding, determined by adding a 50 -fold excess of unlabeled antibody to the incubation media, usually constituted $10-20 \%$ of the total binding and was subtracted to yield specific binding unless otherwise indicated.

Catecholamine release. Catecholamine release was determined as previously described (Kilpatrick et al., 1981; Livett et al., 1983). Cells were loaded with ${ }^{3} \mathrm{H}$-norepinephrine $\left({ }^{3} \mathrm{H}-\mathrm{NE}\right)$ by incubating cultures for 1 $2 \mathrm{hr}$ at $37^{\circ} \mathrm{C}$ with DMEM containing $0.7 \mu \mathrm{Ci}{ }^{3} \mathrm{H}-\mathrm{NE}$ (diluted with unlabeled NE to a final concentration of $\left.5 \times 10^{-7} \mathrm{M}\right), 1 \mathrm{~mm}$ ascorbic acid, and $2.2 \mathrm{~mm} \mathrm{Ca}^{2+}$. The cultures were then rinsed for $30 \mathrm{~min}$ at $37^{\circ} \mathrm{C}$ in $0.5 \mathrm{ml}$ of the same medium without NE to reduce background radioactivity. Induced release was then measured by incubating the cultures at $37^{\circ} \mathrm{C}$ for either 3 or $5 \mathrm{~min}$ in $0.2 \mathrm{ml}$ rinse solution (lacking BSA and containing $2.2 \mathrm{mM} \mathrm{CaCl}_{2}$ and $1 \mathrm{~mm}$ ascorbic acid) supplemented either with $L$-nicotine (at the indicated concentration) for nicotine-induced release or with $\mathrm{KCl}$ to a final concentration of $54 \mathrm{~mm}$ for $\mathrm{K}^{+}$-induced release. Control experiments showed that induced release was linear with time of exposure to agonist for at least $5 \mathrm{~min}$. Usually, rates of basal release were determined in the same cultures both before and after periods of induced release by incubating the cultures under the same conditions in the absence of nicotine or elevated $\mathrm{K}^{+}$concentrations. Radioactivity present in samples of release media and cell lysates (obtained by scraping cultures into $0.6 \mathrm{~N} \mathrm{NaOH}$ ) was determined by liquid scintillation with a Beckman LS-100C counter using Aquasol-2 as a solvent and fluor. Similar counting efliciencies were obtained with the 2 types of samples. ${ }^{3} \mathrm{H}-\mathrm{NE}$ release is expressed as a percentage of the total radioactivity in the cells prior to each test interval.

Other procedures. Protein determinations were carried out by rinsing cultures 4 times with $1 \mathrm{ml}$ aliquots of rinse solution lacking BSA, scraping the cells in $0.5 \mathrm{ml} 0.6 \mathrm{~N} \mathrm{NaOH}$, diluting with an additional $0.5 \mathrm{ml}$ of $0.4 \mathrm{~N} \mathrm{NaOH}$, and assaying for protein by the method of Lowry et al. (1951). BSA was used as a standard, and blanks were determined by assaying culture wells maintained with medium but lacking cells.

The number of chromaffin cells surviving in culture was determined by cell counts after neutral red staining as previously described (Stuart et al., 1974; Role and Perlman, 1980; Livett, 1984). Modulation experiments were performed by incubating cultures for the indicated time in $0.3 \mathrm{ml}$ of culture medium supplemented with the indicated agents, rinsing the cultures, and assaying for specific ${ }^{125} \mathrm{I}-\mathrm{mAb} 35$ binding. In all cases data points represent the mean \pm SEM of triplicate cultures unless otherwise indicated.

Materials. DMEM was obtained from Grand Island Biological Co. fetal bovine serum from Whitakker M.A. Bioproducts, penicillin $\mathrm{G}$ and streptomycin from Microbiological Associates, Percoll from Pharmacia, collagenase from Boehringer-Mannheim, $\mathrm{Na}^{125}$ from Amersham, and ${ }^{3} \mathrm{H}-\mathrm{NE}$ and Aquasol-2 from New England Nuclear. Bgt 3.1 was purified from Bungarus multicinctus venom (Miami Serpentarium) as previously described (Ravdin and Berg, 1979; Ravdin et al., 1981). DNase, BSA, NE, $d$-tubocurarine chloride, carbamylcholine chloride, $L$-nicotine sulfate, cytosine arabinoside, 5 -fluorodeoxyuridine, and ascorbic acid were obtained from Sigma.

\section{Results}

\section{$m A b 35$ binding}

Binding of ${ }^{125} \mathrm{I}-\mathrm{mAb} 35$ to chromaffin cells in culture was examined by incubating the cells with labeled antibody, rinsing, and determining the amount of bound radioactivity. At $37^{\circ} \mathrm{C}$ binding reached maximum levels in $60 \mathrm{~min}$ (Fig. 1A) and was proportional to the number of cells plated over the range of 1$5 \times 10^{5}$ cells per culture (Fig. $1 B$ ). At higher plating densities, neither the amount of ${ }^{125} \mathrm{I}-\mathrm{mAb} 35$ binding (Fig. $1 B$ ) nor the amount of protein per culture (data not shown) increased proportionately. Apparently cell survival and/or cell growth was less efficient at high cell densities in culture. For most experiments, cultures were prepared with $5 \times 10^{5}$ cells $/ 16 \mathrm{~mm}$ well.

mAb 35 binding to bovine chromaffin cells in culture was saturable and specific in that anti-MIR mAbs 6 and 203 blocked ${ }^{125} \mathrm{I}-\mathrm{mAb} 35$ binding to the same extent as did unlabeled $\mathrm{mAb}$ 35 (Fig. 2). Neither mAb 111, a mAb of the same antibody subclass as $\mathrm{mAb} 35$ but of different specificity, nor nonimmune rat serum at a comparable immunoglobulin concentration blocked the ${ }^{125} \mathrm{I}-\mathrm{mAb} 35$ binding (Fig. 2). 


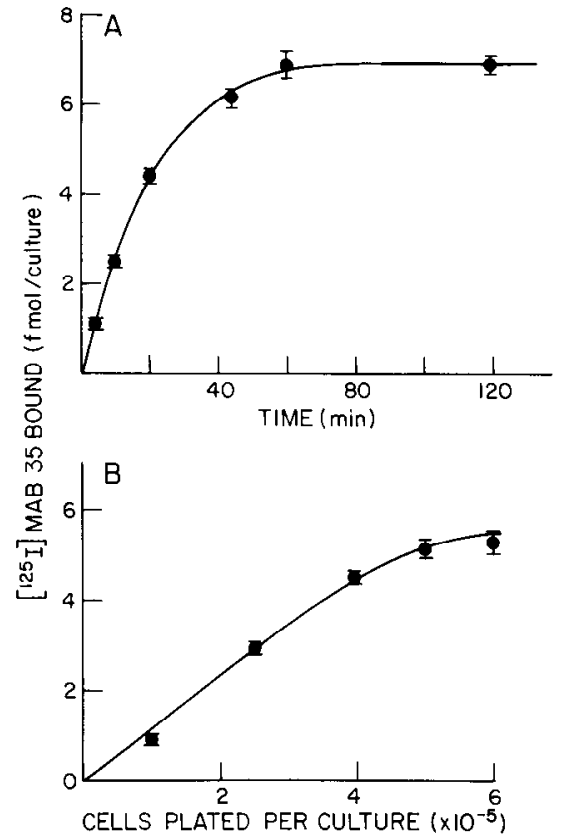

Figure 1. Time dependence and proportionality to number of cells for $\mathrm{mAb} 35$ binding. Specific ${ }^{125} \mathrm{I}-\mathrm{mAb} 35$ binding was determined for cultures of bovine chromaffin cells under standard conditions, varying either the time of binding as indicated $(A)$ or the number of cells plated per well $(B)$. Similar results were obtained in 4 additional experiments as in $A$ and 3 additional experiments as in $B$.

Near-saturation of binding was achieved with $5 \mathrm{nM}^{125} \mathrm{I}-\mathrm{mAb}$ 35 (Fig. 3). Scatchard analysis revealed a single class of highaffinity sites with an apparent equilibrium dissociation constant, $K_{D}$, of $2.1 \pm 0.2 \mathrm{~nm}(n=4)$. This value agrees well with the affinity of both a putative AChR from chicken brain $\left(K_{D}=2\right.$ nM) (Whiting and Lindstrom, 1986), and the AChR of chick ciliary ganglion neurons in culture $\left(K_{D}=1.5 \mathrm{nM}\right)$ for ${ }^{125} \mathrm{I}-\mathrm{mAb}$ 35 (Smith et al., 1986). The $B_{\max }$ for binding from Scatchard

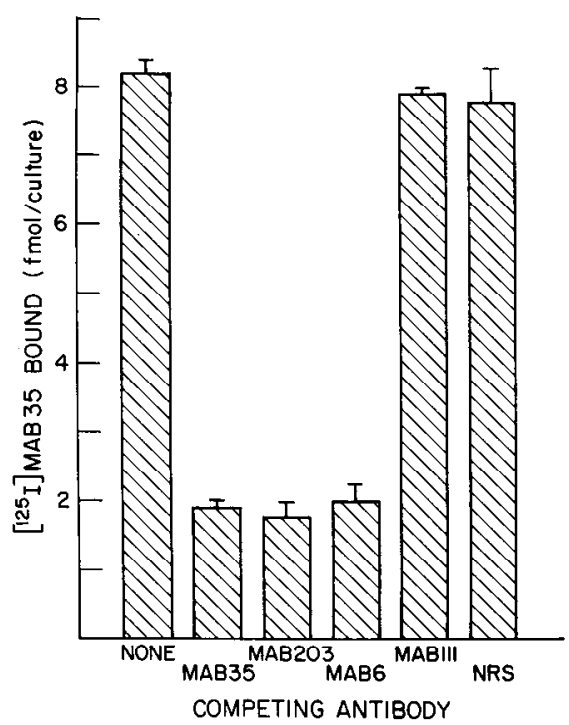

Figure 2. Specificity of antibody binding. The indicated unlabeled antibodies were incubated at $0.25 \mu \mathrm{M}$ along with ${ }^{125} \mathrm{I}-\mathrm{mAb} 35$ in the standard binding assay, and the cultures were examined for total ${ }^{12.5} I-$ $\mathrm{mAb} 35$ binding. Nonspecific binding was not subtracted. Similar results were obtained in 2 other experiments.

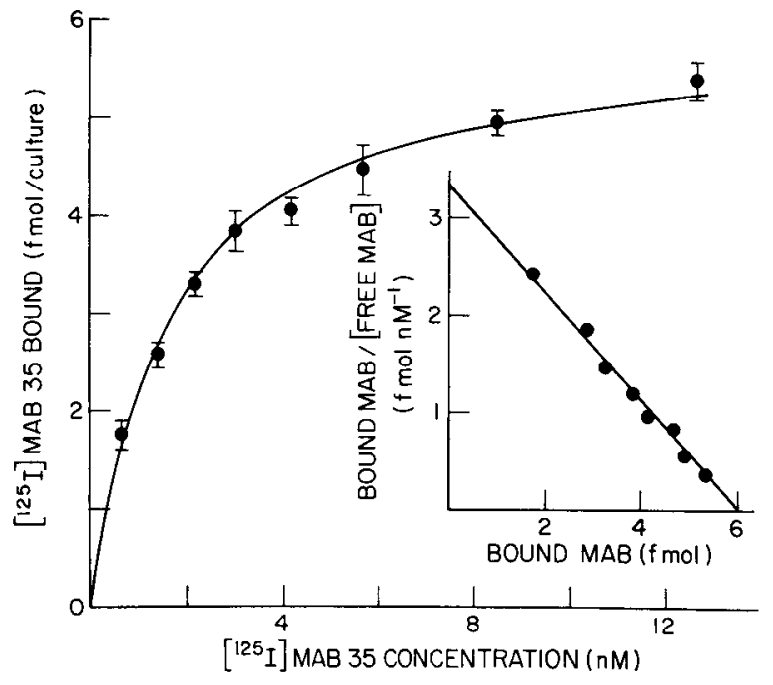

Figure 3. Concentration dependence of $\mathrm{mAb} 35$ binding. Cultures of chromaffin cells were incubated with the indicated concentration of ${ }^{125} I-$ $\mathrm{mAb} 35$ under standard binding conditions and analyzed for specific ${ }^{125} \mathrm{I}-\mathrm{mAb} 35$ binding. Scalchard analysis of the data (inset) indicates a $K_{D}$ of $1.8 \mathrm{nM}$ and a $B_{\max }$ of $6.05 \mathrm{fmol}$ per culture for this experiment.

analysis was $7.8 \pm 0.5(n=5) \mathrm{fmol} /$ culture or $65 \pm 7(n=11)$ $\mathrm{fmol} / \mathrm{mg}$ protein.

The amount of ${ }^{125} \mathrm{I}-\mathrm{mAb} 35$ binding per well reached a maximum by day 2 in culture and remained constant through at least day 10 (data not shown). Rates of protein and RNA synthesis, as well as levels of enzyme activity for catecholamine synthesis, have also been found to remain constant during this period; ${ }^{3} \mathrm{H}$-thymidine labeling indicates the chromaffin cells are not dividing in culture (Kilpatrick et al., 1980). Apparently the cells do not grow significantly after the first day or two. Nearly all of the cells surviving in culture could be stained by neutral red, suggesting they were chromaffin cells (Role and Perlman, 1980; Livett, 1984). The number of such cells represented $60 \%$ of the cells initially plated. Expressing the $B_{\max }$ value on a per cell basis indicated an average site density of $1.6 \pm 0.1 \times 10^{4}$ $\mathrm{mAb} 35$ binding sites per chromaffin cell in culture.

\section{Blockade of AChR function by Bgt 3.1}

Effects of Bgt 3.1 on chromaffin AChR function were examined by monitoring relative levels of nicotine-induced catecholamine release from bovine chromaffin cells in culture. Catecholamine release was measured by first loading the cells with ${ }^{3} \mathrm{H}-\mathrm{NE}$, washing the cells, and then inducing release by exposure to secretogogues. Secretion of preloaded catecholamines has been shown to be an accurate index of endogenous catecholamine release under the conditions used here and has been employed extensively as an assay of AChR function (Mizobe et al., 1979; Kilpatrick et al., 1980; Trifaro and Lee, 1980; Trifaro and Bourne, 1981; Role and Perlman, 1983). Over the range of $L$-nicotine concentrations tested, $10^{-5} \mathrm{M}$ had the greatest effect: $17 \%$ of the total ${ }^{3} \mathrm{H}-\mathrm{NE}$ associated with the cells was released during a 5 min incubation (Fig. 4A). By 10 min the rate of release in $10^{-5}$ $M$ nicotine had declined to the basal rate of $1 \%$ of the total radioactivity associated with the cells per minute (data not shown). $d$-Tubocurarine, a nicotinic antagonist, at $10^{-4} \mathrm{M}$ completely blocked the nicotine-induced release of ${ }^{3} \mathrm{H}-\mathrm{NE}$ from the cells (Fig. 4B).

Bgt 3.1, which reversibly blocks the electrophysiological re- 


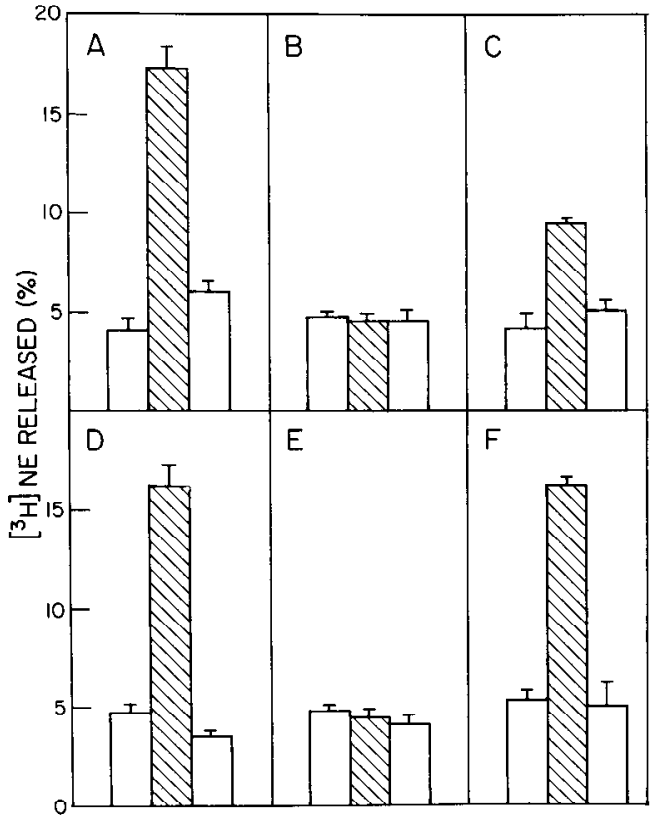

Figure 4. Release of catecholamines by chromaffin cells in culture. Cells were loaded with ${ }^{3} \mathrm{H}-\mathrm{NE}$, washed, and analyzed for secretion of radioactivity during a $5 \mathrm{~min}$ interval. Results are expressed as a percentage of the total radioactivity associated with the cell cultures at the beginning of each release period. In each panel the first and last bars represent basal release measured immediately before and after the experimental treatment, respectively. Treatments, indicated by the hatched bars, were $(A) 10^{-5} \mathrm{M}$ nicotine, $(B) 10^{-3} \mathrm{M}$ nicotine with $10^{-4} \mathrm{M} d$-tubocurarine, (C) $10^{-5} \mathrm{M}$ nicotine with $10^{-7} \mathrm{M}$ Bgt 3.1 , (D) $54 \mathrm{~mm} \mathrm{~K}$, (E) $54 \mathrm{mM} \mathrm{K}^{+}$in the absence of added $\mathrm{Ca}^{2+}$ and the presence of $1 \mathrm{~mm}$ EDTA, $(F) 54 \mathrm{~mm} \mathrm{~K} \mathrm{~K}^{+}$and $10^{-7} \mathrm{M}$ Bgt 3.1. Incubations with Bgt 3.1 also included an hour pretreatment with the toxin to allow equilibration prior to the release period. The values represent the mean + SFM of 10 experiments for $A, 5$ for $B$ and $D-F$, and 7 for $C$, with an experiment including 3 cultures for each determination.

sponse of chick ciliary ganglion neurons to ACh (Ravdin and Berg, 1979; Ravdin ct al., 1981), also blocks the secretory response of bovine chromaffin cells to nicotine. At $10^{-7} \mathrm{M}$, Bgt 3.1 inhibited greater than half of the nicotine-induced catecholamine release from the cells (Fig. 4C). The blockade is likely to occur at the level of AChRs because Bgt 3.1 treatment did not alter the amount of $\mathrm{Ca}^{2+}$-dependent release caused by elevated $\mathrm{K}^{+}$concentrations (Fig. $4, D-F$ ). At $10^{-6} \mathrm{M}$, Bgt 3.1 inhibited about $60 \%$ of the release (Fig. 5). This is substantially less than the $99 \%$ inhibition of the electrophysiological response to $\mathrm{ACh}$ seen with ciliary ganglion neurons exposed to $10^{-7} \mathrm{M}$ Bgt 3.1 (Ravdin and Berg, 1979). It was not practical to test higher concentrations of $\mathrm{Bgt} 3.1$ to determine whether complete blockade of nicotine-induced catecholamine release could be obtained. Possibly only a portion of the release can be inhibited by Bgt 3.1 or a heterogeneity may exist with respect to chromaffin AChR affinities for Bgt 3.1. In any case, it is clear that a substantial fraction of the AChR-mediated catccholaminc rclease can be blocked by Bgt. 3.1.

\section{Modulation of $m A b 35$ sites by Bgt 3.1}

Linkage between mAb 35 binding sites and functional AChRs on bovine chromaffin cells can be inferred from modulation of the antibody binding sites by Bgt 3.1. Bgt 3.1 did not compete with ${ }^{125} \mathrm{I}-\mathrm{mAb} 35$ for binding to chromaffin cells (data not shown). A $24 \mathrm{hr}$ exposure of the cells to Bgt 3.1, however, produced a

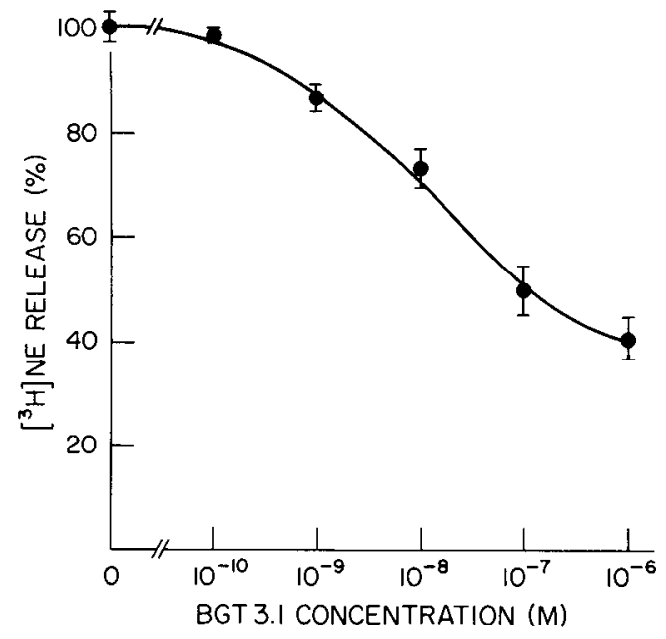

Figure 5. Concentration dependence for Bgt 3.1-mediated inhibition of nicotine-induced catecholamine release. Cultures were loaded with ${ }^{3} \mathrm{H}-\mathrm{NE}$, washed, incubated with the indicated concentration of Bgt 3.1 for $1 \mathrm{hr}$ at $37^{\circ} \mathrm{C}$, and then assayed for release of ${ }^{3} \mathrm{H}-\mathrm{NE}$ by $10^{-5} \mathrm{M}$ nicotine during a $5 \mathrm{~min}$ period in the continued presence of Bgt 3.1 . The amount of release observed is expressed as a percentage of the release obtained in the absence of Bgt 3.1 treatment. Basal release has been subtracted in all cases. The results represent the mean \pm SEM of values averaged from 3 experiments, with each experiment including 3 cultures for each determination.

marked reduction in the amount of mAb 35 binding (Fig. 6). The extent and concentration dependence of the effect were essentially identical to those observed for Bgt 3.1 inhibition of nicotine-induced catecholamine relcasc (cf. Figs. 5, 6). These results suggest that the same Bgt 3.1 binding sites are likely to be responsible for blocking AChR function and for modulating $\mathrm{mAb} 35$ binding to the cells.

To investigate whether modulation of $\mathrm{mAb} 35$ binding sites by Bgt 3.1 is mediated by a cholinergic site, we examined the ability of cholinergic ligands to protect against the Bgt 3.1-induced modulation. Exposure of the cells to $10^{8} \mathrm{M}$ Bgt 3.1 for

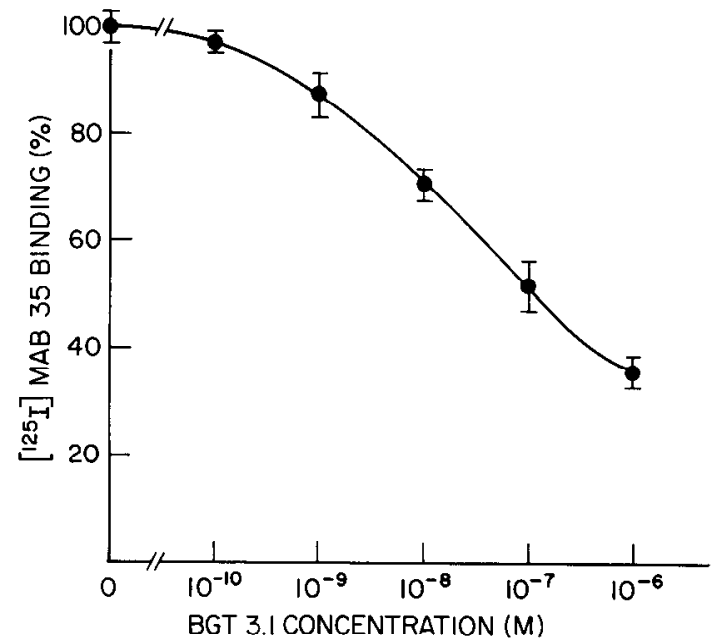

Figure 6. Modulation of $\mathrm{mAb} 35$ binding sites by Bgt 3.1. Cultures were incubated for $24 \mathrm{hr}$ in the indicated concentration of Bgt 3.1, washed, and assayed for specific ${ }^{125} \mathrm{I}-\mathrm{mAb} 35$ binding. Results are expressed as a percentage of the binding obtained in untreated sister cultures, and represent the mean $\perp$ SEM of data from 5 separate experiments, with each experiment including 3 cultures for each $\mathrm{Bgt} 3.1$ concentration. 
Table 1. Effects of cholinergic ligands on modulation by Bgt 3.1

$\begin{array}{cll}\begin{array}{l}\text { Time } \\ (\mathrm{hr})\end{array} & \text { Treatment } & \begin{array}{l}{ }^{125} \mathrm{I}-\mathrm{mAb} \\ 35 \text { binding } \\ (\%)\end{array} \\ 2 & \text { Bgt } 3.1 & 76 \pm 3(7) \\ & \text { Bgt } 3.1+d \text {-TC } & 92 \pm 4(5) \\ & \text { Bgt } 3.1+\text { carbamylcholine } & 90 \pm 3(5) \\ 24 & \text { Bgt } 3.1 & 73 \pm 2(7) \\ & \text { Bgt } 3.1+d \text {-TC } & 94 \pm 1(6) \\ & \text { Bgt 3.1 + carbamylcholine } & 79 \pm 2(6) \\ & \text { Carbamylcholine } & 81 \pm 2(6)\end{array}$

Cultures were treated with the indicated agents for either 2 or $24 \mathrm{hr}$, washed, and then assayed for specific ${ }^{125} \mathrm{I}-\mathrm{mAB} 35$ binding. Results are expressed as percentage of binding levels obtained in untreated sister cultures. Bgt $3.1,10^{-8} \mathrm{M} ; d-\mathrm{TC}, 10^{-4}$ M $d$-tubocurarine; carbamylcholine $10^{-4} \mathrm{M}$. The values represent the mean \pm SEM for the number of experiments indicated in parentheses, with experiments including 3 cultures for each determination.

$2 \mathrm{hr}$ caused a reduction in $\mathrm{mAb} 35$ binding that was largely prevented when either the cholinergic antagonist $d$-tubocurarine or the cholinergic agonist carbamylcholine was included in the incubation with Bgt 3.1 (Table 1). Long-term modulation (24 hr) was also blocked by $d$-tubocurarine, but the effects of carbamylcholine were more complicated under these conditions. Carbamylcholine alone induced a decline in $\mathrm{mAb} 35$ binding on chromaffin cells equal to the effect seen with Bgt 3.1 plus carbamylcholine (Table 1). The carbamylcholine effect represents a direct cholinergic modulation of the mAb 35 binding component on chromaffin cells as previously demonstrated for the $\mathrm{mAb} 35$ binding component on ciliary ganglion neurons in culture (Smith et al., 1986) and AChRs on skeletal myotubes in culture (Gardner and Fambrough, 1979). Most likely the cholinergic ligands prevent Bgt 3.1 from binding to the chromaffin AChR, as they do with AChRs on ciliary ganglion neurons (Halvorsen and Berg, 1986a), and thereby prevent the toxin from altering the binding of $\mathrm{mAb} 35$ to the same component.

Modulation of the AChR response by $m A b 35$

To provide further evidence that the mAb 35 binding component on chromaffin cells represents the AChR, we examined the ability of mAb 35 to modulate the secretory response of the cells to cholinergic agonist. Cultures maintained at $37^{\circ} \mathrm{C}$ for 24 $\mathrm{hr}$ in medium supplemented with $7 \mathrm{~nm}$ mAb 35 displayed very little nicotine-induced catecholamine release, even though they had normal levels of ${ }^{3} \mathrm{H}-\mathrm{NE}$ uptake (data not shown), basal release, and $\mathrm{K}^{+}$-induced catecholamine release (Fig. 7). The mAb 35 effect was specific since substitution of either nonimmune rat serum or $\mathrm{mAb} 111$ at comparable immunoglobulin concentrations to that used for mAb 35 had no effect on either nicotine- or $\mathrm{K}^{+}$-induced catecholamine release (Fig. 7). AntiMIR mAbs 6 and 203 at $7 \mathrm{~nm}$ for $24 \mathrm{hr}$ caused the same loss of nicotine-induced catecholamine release as did mAb 35 (data not shown). These results provide the strongest evidence to date of a direct association between an identified surface antigen and the functional AChR on chromaffin cells.

A shorter incubation in $\mathrm{mAb} 35(2 \mathrm{hr})$ reduced the ability of the cells to release catecholamines in response to nicotine by $84 \pm 7 \%(n=4)$. This relatively rapid effect raised the possibility that with the standard ${ }^{125} \mathrm{I}-\mathrm{mAb} 35$ binding conditions, substantial modulation of AChRs may occur. If the modulation represents internalization of receptor, the binding conditions

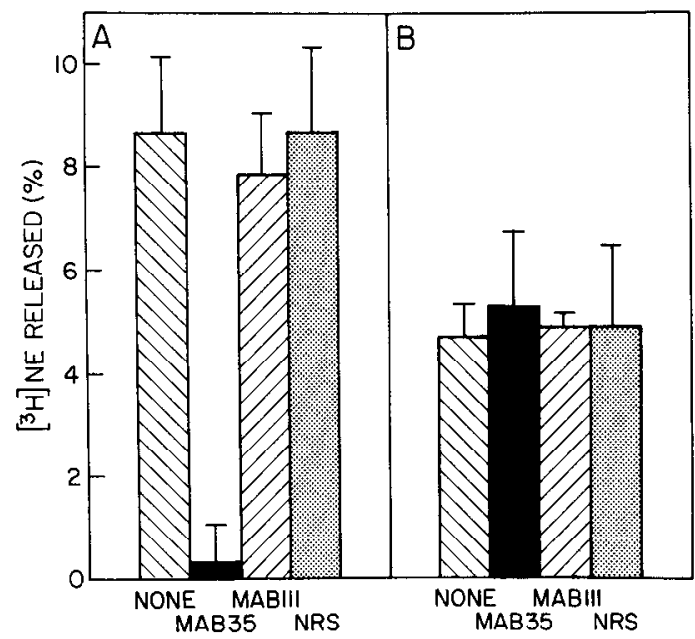

Figure 7. Modulation of nicotine-induced catecholamine release by $\mathrm{mAb} 35$. Cultures were incubated with the indicated antibody at $7 \mathrm{nM}$ for $24 \mathrm{hr}$, washed, loaded with ${ }^{3} \mathrm{H}-\mathrm{NE}$, washed again, and assayed for the release of radioactivity during a $3 \mathrm{~min}$ period induced either by $10^{-6}$ $\mathrm{M}$ nicotine $(A)$ or by $54 \mathrm{~mm} \mathrm{~K}^{\prime}(B)$. None, no antibody; NRS, nonimmune rat serum. Basal rates of release, determined in 3 min periods immediately prior to the test period, were similar for all conditions and were subtracted to yield the values shown for specific release. 'The results are expressed as a percentage of the total radioactivity associated with the cells at the beginning of the test period, and represent the mean \pm SEM of values obtained from 8 experiments, with experiments including 3 cultures for each determination.

might have produced an underestimate for the number of sites by reducing their availability on the cell surface. To test this possibility, ${ }^{125} \mathrm{I}-\mathrm{mAb} 35$ labeling of chromaffin cultures was carried out both at 37 and at $4^{\circ} \mathrm{C}$. In the latter case, temperaturedependent clustering and internalization of membrane components should have been blocked (I Ieinemann et al., 1977). No difference in the number of binding sites per cell was detected at the 2 temperatures (data not shown). Though modulation of the $\mathrm{AChR}$ response by $\mathrm{mAb} 35$ may involve receptor internalization, the modulation does not appear to interfere with the quantitation of receptor number in the standard $\mathrm{mAb} 35$ binding assay used here.

\section{Discussion}

Several lines of evidence indicate that both $\mathrm{mAb} 35$ and Bgt 3.1 recognize the $\mathrm{AChR}$ on bovine chromaffin cells. Scatchard analysis indicates a single class of high-affinity binding sites for mAb 35 on chromaffin cells, with a $K_{D}$ comparable to that for $\mathrm{mAb} 35$ binding to the AChR of chick ciliary ganglion neurons (Halvorsen and Berg, 1986a; Smith et al., 1986). Bgt 3.1 specifically blocks a large portion of the $\mathrm{AChR}$ response of chromaffin cells as reflectcd by inhibition of nicotinc-induced catecholamine release. Bgt 3.1 also specifically modulates the amount of $\mathrm{mAb} 35$ binding on the cells to the same extent and with the same concentration dependence that it influences the AChR response. Moreover, Bgt 3.1-mediated modulation of $\mathrm{mAb} 35$ binding sites can be prevented by co-incubation with cholinergic ligands, and the cholinergic agonist carbamylcholine by itself can directly modulate the mAb 35 binding sites. Lastly, mAb 35 can specifically modulate the magnitude of the chromaffin cell AChR response.

Similar properties have been described for the AChR of chick ciliary ganglion neurons, which has been shown to bind both 
mAb 35 and Bgt 3.1 (Halvorsen and Berg, 1986a, b, 1987). Bgt 3.1 reversibly blocks the electrophysiological response of the neurons to ACh (Ravdin and Berg, 1979; Ravdin et al., 1981) and modulates the number of mAb 35 binding sites on the surface of the cells in culture (Smith et al., 1986). In conjunction with second layer antibody, mAb 35 can modulate the number of Bgt 3.1 sites associated with AChRs on the neurons (Halvorsen and Berg, 1987). In contrast to ciliary ganglion neurons, however, where $10^{-7} \mathrm{M}$ Bgt 3.1 blocks $99 \%$ of the ACh response (Ravdin and Berg, 1979), Bgt 3.1 at $10^{-6} \mathrm{M}$ blocks only about $60 \%$ of the nicotine-induced catecholamine release from bovine chromaffin cells. This, together with the breadth of the Bgt 3.1 concentration curves for both the inhibition of catecholamine secretion and for the modulation of mAb 35 binding, suggests either a heterogeneity in the affinity of chromaffin AChRs for Bgt 3.1 or a nonlinear relationship between the proportion of AChRs occupied by Bgt 3.1 and the magnitude of the affected cellular response.

The mechanism for modulation either by Bgt 3.1 or by $\mathrm{mAb}$ 35 with chromaffin cells is unknown. The mAb 35 modulation of nicotine-induced catecholamine release may be due to effects on chromaffin AChRs similar to the internalization of muscle AChRs induced by anti-AChR antibodies (Heinemann et al., 1977; Lindstrom and Einarson, 1979; Merlie et al., 1979a, b). Modulation by Bgt 3.1 of mAb 35 sites may result from the toxin existing as a dimer (Chiappinelli and Lee, 1985), promoting clustering and internalization of AChRs in a manner analogous to the effects of divalent antibodies. It is unlikely that the inhibition of AChR-mediated secretion by Bgt 3.1 depends on its modulatory effects since inhibition is more rapid, reaching a maximum within minutes, while modulation of $\mathrm{mAb} 35$ binding by Bgt 3.1 requires hours to reach a maximum (data not shown).

Both chick ciliary ganglion neurons and rat pheochromocytoma PC12 cells express a membrane component that binds $\alpha$-Bgt, but the component is distinct from the AChR responsible for the fast depolarizing nicotinic response of the cells (Patrick and Stallcup, 1977b; Jacob and Berg, 1983; Smith et al., 1983, 1985, 1986; Jacob et al., 1984). The function of the $\alpha$-Bgt binding component on these 2 cell types is unknown, though the component has cholinergic pharmacology: cholinergic ligands prevent $\alpha$-Bgt binding (Patrick and Stallcup, 1977a; Ravdin et al., 1981; Smith et al., 1983). Bovine adrenal chromaffin cells also have a membrane component that hinds $\alpha$-Bgt, and, like AChRs from ciliary ganglion neurons (Ravdin and Berg, 1979; Ravdin et al., 1981) and PC1 2 cells (Patrick and Stallcup, 1977a, b), the chromaffin AChR is not inhibited by concentrations of $\alpha$-Bgt adequate to saturate the high-affinity $\alpha$-Bgt binding site on the cells (Trifaro and Lee, 1980; Kilpatrick et al., 1981). The function of the $\alpha$-Bgt binding component on chromaffin cells and its relationship to AChRs identified by mAb 35 and Bgt 3.1 on the cells are unknown.

Chromaffin cells in a number of species have both nicotinic and muscarinic receptors. Catecholamine release is stimulated by nicotinic receptors on bovine chromaffin cells (Mizobe et al., 1979; Livett et al., 1983), while in rat and guinea pig, both nicotinic and muscarinic receptors can stimulate release (Role and Perlman, 1983; Wakade and Wakadc, 1983). In chick, only muscarinic stimulation of catecholamine release has been reported (Ledbetter and Kirshner, 1975). The biological significance of this variation is not known. The similarities between nicotinic receptors of bovine chromaffin cells and those of chick ciliary ganglion neurons with respect to antibody and toxin binding, however, suggest that a number of properties have been conserved for nicotinic receptors among tissues of neural origin and across species. The number of AChRs per bovine chromaffin cell in culture, as identified by ${ }^{125} \mathrm{I}-\mathrm{mAb} 35$ binding, is only about a tenth of that found with chick ciliary ganglion neurons in culture (Smith et al., 1986). The large cell yields from bovine adrenal glands, however, and the number of glands readily obtained make the tissue a possible source of AChRs for structural and regulatory studies. The chromaffin AChR is likely to serve as a useful model for examining the properties of neuronal AChRs.

\section{References}

Chiappinelli, V. A. (1983) Kappa-bungarotoxin: A probe for the neuronal nicotinic receptor in the avian ciliary ganglion. Brain Res. 227. 9-21.

Chiappinelli, V. A., and J. C. Lee (1985) $к$-Bungarotoxin: Self association of a neuronal nicotinic receptor probe. J. Biol. Chem. 260:61826186.

Costa, E., A. Guidotti, I. Hanbauer, and L. Saiani (1983) Modulation of nicotinic receptor function by opiate recognition sites highly selective for $\mathrm{Met}^{5}$-enkephalin ( $\mathrm{Arg}^{6} \mathrm{Phe}^{7}$ ). Fed. Proc. 42: 2946-2952.

Fambrough, D. M. (1979) Control of acetylcholine receptors in skeletal muscle. Physiol. Rev. 59: 165-226.

Gardner, J. M., and D. M. Fambrough (1979) Acetylcholine receptor degradation measured by density labeling: Effects of cholinergic ligands and evidence against recycling. Cell 16: 661-674.

Grant, G. A., and V. A. Chiappinelli (1985) $\kappa$-Bungarotoxin: Complete amino acid sequence of a neuronal nicotinic receptor probe. Biochemistry 24: 1532-1537.

Gullick, W. J., and J. M. Lindstrom (1983) Mapping the binding of monoclonal antibodies to the acetylcholine receptor from Torpedo californica. Biochemistry 22: 3312-3320.

Halvorsen, S. W., and D. K. Berg (1986a) Identification of a nicotinic acetylcholine receptor on neurons using an $\alpha$-neurotoxin that blocks receptor function. J. Neurosci. 6: 3405-3412.

Ilalvorsen, S. W., and D. K. Berg (1986b) Active site subunits of a neuronal acetylcholine receptor examined by crosslinking with an $\alpha$-neurotoxin. Soc. Neurosci. Abstr. 12: 147.

Halvorsen, S. W., and D. K. Berg (1987) Affinity labeling of neuronal acetylcholine receptor subunits with an $\alpha$-neurotoxin that blocks receptor function. J. Neurosci. (in press).

Heinemann, S., S. Bevan, R. Kullberg, J. Lindstrom, and J. Rice (1977) Modulation of acetylcholine receptor by antibody against receptor. Proc. Natl. Acad. Sci. USA 74: 3090-3094.

Higgins, L. S., and D. K. Berg (1986) Identification of a putative acetylcholine receptor on bovine chromaffin cells by monoclonal antibodies to receptor from muscle and electric organ. Soc. Neurosci. Abstr. 12: 961 .

Jacob, M. H., and D. K. Berg (1983). The ultrastructural localization of $\alpha$-bungarotoxin binding sites in relation to synapses on chick ciliary ganglion neurons. J. Neurosci. 3: 260-271.

Jacob, M. H., D. K. Berg, and J. M. Lindstrom (1984) Shared antigenic determinant between the Electrophorus acetylcholine receptor and a synaptic component on chick ciliary ganglion neurons. Proc. Natl. Acad. Sci. USA 81: 3223-3227.

Kilpatrick, D. L., F. H. Ledbetter, K. A. Carson, A. G. Kirshner, R. Slepetis, and N. Kirshner (1980) Stability of bovine adrenal medulla cells in culture. J. Neurochem. 35: 679-435.

Kilpatrick, D. L., R. Slepetis, and N. Kirshner (1981) Ion channels and membrane potentials in stimulus-secretion coupling in adrenal medullary cells. J. Neurochem 36: 1245-1255.

Ledbetter, F. H., and N. Kirshner (1975) Studies of chick adrenal medulla in organ culture. Biochem. Pharmacol. 24: 967-974.

Lindstrom, J., and B. Einarson (1979) Antigenic modulation and receptor loss in experimental autoimmune myasthenia gravis. Muscle Nerve 2: 173-179.

Livett, B. G. (1984) Adrenal medullary chromaffin cells in vitro. Physiol. Rev. 64: 1103-1161.

Livett, B. G., P. Boska, D. M. Dean, F. Mizobe, and M. H. Lindenbaum 
(1983) Use of isolated chromaffin cells to study basic release mechanisms. J. Autonom. Nerv. Syst. 7: 59-86.

Loring, R. H., D. Andrews, W. Lane, and R. E. Zigmond (1986) Amino acid sequence of Toxin $F$, a snake venom toxin that blocks neuronal nicotinic receptors. Brain Res. (in press).

Loring, R. H., V. A. Chiappinelli, R. E. Zigmond, and J. B. Cohen (1984) Characterization of a snake venom neurotoxin which blocks nicotinic transmission in the avian ciliary ganglion. Neuroscience 11 : 989-999.

Lowry, O. H., N. J. Rosenbrough, A. L. Farr, and R. J. Randall (1951) Protein measurement with the Folin phenol reagent. J. Biol. Chem. 193: 265-275.

Merlie, J. P., S. Heinemann, and J. Lindstrom (1979a) Acetylcholine receptor degradation in adult rat diaphragm in organ culture and the effect of anti-acetylcholine receptor antibodies. J. Biol. Chem. 254 $6320-6327$

Merlie, J. P., S. Heinemann, and J. Lindstrom (1979b) Degradation of acetylcholine receptor in diaphragms of rats with experimental autoimmune myasthenia gravis. J. Biol. Chem. 254: 6328-6332.

Mizobe, F., M. Iwamoto, and B. G. Livett (1979) Pharmacological characterization of adrenal paraneurons: Substance $P$ and somatostatin as inhibitor modulators of the nicotinic response. Brain Res. 178: $555-566$.

Patrick, J., and W. B. Stallcup (1977a) Alpha-bungarotoxin binding and cholinergic receptor function on a rat sympathetic nerve line. J. Biol. Chem. 252: 8629-8633.

Patrick, J., and W. B. Stallcup (1977b) Immunological distinction between acetylcholine receptor and the $\alpha$-bungarotoxin binding component on sympathetic neurons. Proc. Natl. Acad. Sci. USA 74:46894692.

Ravdin, P. M., and D. K. Berg (1979) Inhibition of neuronal acetylcholine sensitivity by alpha-toxins from Bungarus multicinctus venom. Proc. Natl. Acad. Sci. USA 76: 2072-2076.

Ravdin, P. M., R. M. Nitkin, and D. K. Berg (1981) Internalization of $\alpha$-bungarotoxin on neurons induced by a neurotoxin that blocks neuronal acetylcholine sensitivity. J. Neurosci. 1 : 849-861.

Role, L. W., and R. L. Perlman (1980) Purification of adrenal medullary cells by density gradient centrifugation. J. Neurosci. Methods 2: 253-265.

Rolc, L. W., and R. L. Pcrlman (1983) Both nicotinic and muscarinic receptors mediate catecholamine secretion by isolated guinea-pig chromaffin cells. Neuroscience 10:979-985.

Saiani, L., H. Kageyama, B. M. Conti-Tronconi, and A. Guidotti (1984) Purification and characterization of a bungarotoxin polypeptide that blocks nicotinic receptor function in primary culture of adrenal chromaffin cells. Mol. Pharmacol. 25: 327-334.
Smith, M. A., J. F. Margiotta, and D. K. Berg (1983) Differential regulation of acetylcholine sensitivity and $\alpha$-bungarotoxin-binding sites on ciliary ganglion neurons in cell culture. J. Neurosci. 3: 23952402 .

Smith, M. A., J. Stollberg, J. M. Lindstrom, and D. K. Berg (1985) Characterization of a component in chick ciliary ganglia that crossreacts with monoclonal antibodies to muscle and electric organ acetylcholine receptor. J. Neurosci. 5: 2726-2731.

Smith, M. A., J. F. Margiotta, A. Franco, Jr., J. M. Lindstrom, and D. K. Berg (1986) Cholinergic modulation of an acetylcholine receptorlike antigen on the surface of chick ciliary ganglion neurons in cell culture. J. Neurosci. 6: 946-953.

Stollberg, J., P. J. Whiting, J. M. Lindstrom, and D. K. Berg (1986) Functional blockade of neuronal acetylcholine receptors by antisera to a putative receptor from brain. Brain Res. 378: 179-182.

Stuart, A. E., A. J. Hudspeth, and Z. W. Hall (1974) Vital staining of specific monoamine-containing cells in the leech nervous system. Cell Tissue Res. 153: 55-61.

Trifaro, J. M., and G. W. Bourne (1981) Differential effects of concanavalin A on acetylcholine and potassium-evoked release of catecholamines from cultured chromaffin cells. Neuroscience 6: 18231833.

Trifaro, J. M., and R. W. H. Lee (1980) Morphological characteristics and stimulus-secretion coupling in bovine adrenal chromaffin cell cultures. Neuroscience 5: 1533-1546.

Tzartos, S. J., and J. M. Lindstrom (1980) Monoclonal antibodies used to probe acetylcholine receptor structure: Localization of the main immunogenic region and detection of similarities between subunits. Proc. Natl. Acad. Sci. USA 77: 755-759.

Tzartos, S. J., D. E. Rand, B. L. Einarson, and J. M. Lindstrom (1981) Mapping of surface structure of Electrophorus acetylcholine receptor using monoclonal antibodies. J. Biol. Chem. 256: 8635-8645.

Tzartos, S., L. Langeberg, S. Hochschwender, and J. Lindstrom (1983) Demonstration of a main immunogenic region on acetylcholine receptors from human muscle using monoclonal antibodies to human receptor. FEBS Lett. 158: 116-118.

Wakade, A. R., and T. D. Wakade (1983) Contribution of nicotinic and muscarinic receptors in the secretion of catecholamines evoked by endogenous and exogenous acetylcholine. Neuroscience 10:973978.

Whiting, P. J., and J. Lindstrom (1986) Purification and characterization of an acetylcholine receptor from chick brain. Biochemistry 25. $2082-2093$. 